\title{
INTERNATIONAL CLASS SOLIDARITY OR FOREIGN INTERVENTION?
}

\author{
INTERNATIONALISTS AND LATVIAN RIFLES IN THE RUSSIAN \\ REVOLUTION AND THE CIVIL WAR
}

Lenin made the Revolution with Jewish brains, Russian stupidity and Latvian swords.

Anti-Bolshevik joke in Russia of the years after the Revolution'

More or less by definition, civil war refers to an armed conflict between citizens of the same country. However, the two outstanding European examples of this century, the civil wars in Spain and Russia, were in fact complicated by foreign intervention. Indeed, in the case of Spain, intervention by foreign powers proved decisive.

The Russian Civil War witnessed the involvement of military forces from virtually every conceivable major foreign power (England, France, USA, Germany, Japan). In Soviet historiography, as well as for some Western revisionist historians, the significance of this foreign involvement has been raised to the level of myth. In fact, their initial presence was the direct consequence of strategic concerns arising in the World War in progress at the outbreak of the Revolution. Furthermore, for the duration of the Civil War there was at most only a minimal level of co-ordination amongst the foreign forces, and at no time were any of these troops to play a significant role in the fighting between Reds and Whites. However, financial support to the Whites, in particular by the British, was by contrast relatively important.

In addition, both the Spanish and Russian civil wars witnessed extensive participation by foreigners, acting independently of their governments. This form of foreign intervention has often been referred to by its advocates as "internationalism", being in their view an expression of class solidarity in the international labour movement, though, of course, this participation has been on both sides of the warring factions. In the Russian Civil War the former prisoners of war of the Czech Legion and other foreigners rose in revolt against the Bolsheviks. In the Spanish Civil War the Nationalist side 
also included more than sixty thousand "Moors" or Moroccans, and individuals from several countries, including a few emigrated Russians.

More closely identified with internationalism as mentioned above, are the forty thousand foreigners who fought on the Republican side, most of them in the International Brigades. As was noted by Hugh Thomas,

there was a precedent for this international force in the Red Army, during the Russian civil war. The designation "International Brigade" had even been used, along with other names such as First International Legion of the Red Army, the International Red Army, and the First Revolutionary International Detachment. Into these forces in support of the revolution in Russia there had been pressed innumerable volunteers, or ex-prisoners of war from Austro-Hungarian or German or Bulgarian armies from out of the waves of men who had been washed into Russia by the First World War. [ . . ] Presumably it seemed very convenient to Stalin if an experiment which had once been effectively tried out in one [the Russian] civil war might be employed again in another [the Spanish civil war]. ${ }^{2}$

In fact, some of the leading officers in the International Brigades began as internationalists in the Russian Civil War. The famous General Kléber, as well as General Lukács and (a third pseudonym) Colonel Gall, prisoners of war from the Austro-Hungarian army during the First World War, had joined the internationalist units fighting for the Bolsheviks. The Croatian Vladimir Copić also fought with the Austrian army at the Russian front. After being taken prisoner he went over to the Bolshevik side; in the Spanish Civil War he served as a Lieutenant Colonel. The Polish General Walter (pseudonym) had first served in the Russian army in the World War and subsequently took part in the Russian Civil War. ${ }^{3}$ These similarities and links should not be stressed too much; as I hope to make clear, there were many differences as well. We now proceed with a more detailed examination of the internationalists in the Russian Civil War, and the ensuing debate regarding their role.

In any political upheaval, there is an inclination on the part of many to attribute their difficulties to the influence of foreign forces, from within or without the country. So, from 1917 on until today, some of the Russian antiCommunists have claimed that the October Revolution and Bolshevik rule are basically non-Russian phenomena. The arguments presented are wellknown. Its ideology, Marxism, originated in the West. In the revolutionary movement Jews and other non-Russians played a disproportionately important role. Lenin, who according to Solzhenitsyn was no more than

${ }^{2}$ H. Thomas, The Spanish Civil War, 3rd ed. (Harmondsworth, 1977), pp. 452f.

${ }^{3}$ Ibid., pp. 455f., 459, 482, 590f. 
quarter Russian, ${ }^{4}$ gained power with the aid of German money. Finally, as has repeatedly been stressed, the Bolsheviks in the first years after taking over power were dependent on military assistance of Latvians, Hungarians, Chinese and other internationalists, and it has been argued that without these foreign forces (chuzhaia sila) 5 they could not have survived. "The Soviet regime has been forced upon us by the gold of the enemy [Germany], his aid, and foreign bayonets", writes the Russian émigré historian Iu. Srechinskii. ${ }^{6}$

Already during the Revolution and the Civil War anti-Communists, both on the Left and the Right, accused the Bolsheviks of relying on foreign armed forces. In August 1918 the Menshevik Aksel'rod and the Socialist Revolutionaries Gavronskii, Rusanov and Sukhomlin in a statement addressed to the Socialist parties of all countries alleged that "to secure for themselves the autocracy the Bolshevik rulers have created an army of mercenaries, consisting partly of Russian workers, partly, however, of Latvians and Chinese as well as German and Austrian prisoners of war, which assumes an especially privileged status, enjoying an absolute impunity, so that the entire country is exposed to pillage and murder"?

At a Socialist Revolutionary Party meeting held in 1919 the Red Army of 1918 was characterized as "praetorian, consisting partly of elements which, resulting from the arbitrariness of the fortunes of war, are entirely estranged from their home country, such as the Latvian Rifles, former Hungarian prisoners of war and Chinese mercenaries [naemnye kitaitsy], and partly of declassed remnants of the disintegrated army". ${ }^{8}$ Elsewhere we find similar allegations. ${ }^{9}$ However, also in Bolshevik sources the Latvians,

${ }^{4}$ A. Solzhenitsyn, Lenin v Tsiurikhe (Paris, 1975), p. 87.

5 N. A. Nefedov in Veche, No 4 (1982), pp. $129 f$.

${ }^{6}$ Novoe Russkoe Slovo, June 12, 1966.

7 Stimmen aus Russland, No 4-5 (August 15, 1918), p. 3; Aux Partis Socialistes du monde entier. Appel à l'Internationale de la Délégation russe du Parti socialdémocrate et du Parti socialiste-révolutionnaire à l'étranger (Stockholm, 1918), p. 5.

8 Resolution on the attitude towards the Red Army, adopted at the Ninth Party Council of the PSR, Moscow, June 18-20, 1919, PSR Archive, No 2010, Internationaal Instituut voor Sociale Geschiedenis, Amsterdam.

9 See, e.g., the Left Socialist Revolutionary Mariia Spiridonova: Pravda, December 29, 1918; another statement by the Left Socialist Revolutionaries: P. Scheibert, Lenin an der Macht (Weinheim, 1984), p. 429; the leader of the PSR, Viktor Chernov: V. Chernov, "Chernovskaia gramota" i Ufimskaia Direktoriia, p. 17, Nicolaevsky Collection, No $7 / 55$, Hoover Institution, Stanford; the right-wing Socialist Revolutionary I. I. BunakovFondaminskii: La Russie Démocratique, No 4 (July 16, 1919); the former Socialist Revolutionary Boris Savinkov: Le Débat, No 31 (1984), p. 184; an Ukrainian MilitaryRevolutionary Committee: W. H. Chamberlin, The Russian Revolution 1917-1921 (London, 1935), II, p. 225; the Anarchist Petr Arshinov reporting on the deployment of 
Hungarians and Chinese at times figure prominently.

In an attempt to explore the background of these forces, and the reasons for their participating in the Russian Civil War, one must bear in mind that the Russian Empire before the Revolution, as much as the Soviet Union thereafter, formed a multinational state. Prior to the Revolution Russians accounted for slightly less than half of the population; after the Revolution slightly more. Before the Revolution Latvia, together with the other Baltic territories, was part of the Russian Empire, and following the Second World War it has been part of the Soviet Union. Dissatisfaction amongst non-Russians with Russian rule was indeed one cause of the Revolution.

Moreover, during the First World War several millions of foreigners had come to Russia. Of these two million Germans, Austrians, Hungarians, Czechs and others were prisoners of war interned for the most part in Siberian camps. The remainder consisted of immigrants, refugees and hired labour, Finns, Persians, Chinese, Koreans, etc. Particular mention may be made of some hundreds of thousands Chinese and Korean labourers who were employed in Siberia.

In October 1917, when the Bolsheviks came to power, the old army had disintegrated. What was left could only partially be used by the new rulers. To remain in power they had to create a new army. In part they recruited from the prisoners of war, forming internationalist units, a measure which in their view was a natural step towards world revolution. The Decree on Peace had won the Bolsheviks some credit with the prisoners of war, who were anxious to return home. But this was not possible until the war had come to an end. The decree also proclaimed the right of national selfdetermination. Improvement in condition of the prisoners of war had a further stimulating effect.

The internationalist units were augmented by other foreigners then resident in Russia. It is not quite certain how many soldiers were recruited in this manner. Estimates run up to fifty thousand in the year 1918 alone, ${ }^{10}$ and 250-300,000 during the entire period of the Civil War. ${ }^{11}$ These esti-

Latvians and Chinese against Makhno in 1920: P. Arshinov, Istoriia makhnovskogo dvizheniia (Berlin, 1923), p. 158.

$10 \mathrm{~J}$. Erickson, The Soviet High Command (London, 1962), p. 675; M. Frenkin in Crossroads, No 3 (1979), p. 131; D. Footman, Civil War in Russia (London, 1961), p. 138; J. Bunyan, Intervention, Civil War, and Communism in Russia (Baltimore, 1936), p. 96.

11 The Modern Encyclopedia of Russian and Soviet History, XIV (1979), p. 212; Bol'shaia Sovetskaia EntsikJopediia, 3rd ed., X (1972), p. 332; Sovetskaia Istoricheskaia Entsiklopediia, VI (1965), p. 160; Grazhdanskaia Voina i Voennaia Interventsiia v SSSR. Entsiklopediia (Moscow, 1983), p. 235; Iu. Srechinskii in Novoe Russkoe Slovo, May 29 and June 12, 1966. 
mates, however, have been subject to dispute.

The Latvian rifle units dated from Tsarist rule. It had, however, not been Tsarist policy to form army units based on non-Russian nationality. ${ }^{12}$ Under pressure of the German advance in the Baltic in 1915 an exception was made with respect to the Latvians. As a result of their fighting spirit and discipline in action against the Germans the force of the "Latvian Rifles" was gradually expanded from two battalions to eight regiments. After the February Revolution of 1917 they came increasingly under Bolshevik influence, and when the Bolsheviks took over, they could rely on many of these Latvians as being their most loyal supporters. The German historian P. Scheibert, discussing Bolshevik rule of the period of the October Revolution, writes: "Without the reliable Latvian Rifles they would hardly have survived." 13

During the October Revolution Latvian Rifles occupied some of the strategically important railway stations in the Baltic region, to prevent proKerenskii armies from marching on Petrograd. Within a few days a Latvian regiment of 2,500 men and a battalion of a few hundred men came to Petrograd to maintain order in the city and to protect the seat of the new Government, the Smol'nyi Institute. When, in January 1918, the Constituent Assembly (Parliament) was dissolved, Latvian Rifles were among the forces that surrounded the Tauride Palace, the seat of the Assembly, and violently broke up demonstrations in favour of the Assembly. Trotskii mentions that Lenin particularly favoured using Latvians to dissolve the Constituent Assembly. ${ }^{14}$

Latvians accompanied the Soviet Government when in March 1918 it moved from Petrograd to Moscow, and in the new capital they once more mounted guard at the seat of government, this time at the Kremlin. On April 30th the German Ambassador Mirbach reported to his Government: "The supremacy of the Bolsheviks in Moscow is principally upheld by the Livonian [Latvian] battalions". ${ }^{15}$ In July 1918, when the Left Socialist Revolutionaries in Moscow staged a rebellion, the Government had only the Latvian Rifles and a unit of internationalists under the Hungarian

12 I.e., since the military reforms of 1874 ; before that time the Russian army included so-called "inorodnye voiska" or "troops of different nationalities", S. L. Curran and D. Ponomareff, "Managing the Ethnic Factor in the Russian and Soviet Armed Forces: An Historical Overview", in: Conflict, IV (1982), pp. 239-300, especially pp. 241-47.

${ }_{13}$ Scheibert, Lenin an der Macht, op. cit., p. 60.

${ }^{14}$ L. D. Trotskii, O Lenine, 2nd ed. (Moscow, n.d.), p. 67.

15 Germany and the Revolution in Russia 1915-1918, ed. by Z. A. B. Zeman (London, 1958), p. 121. 
Béla Kun at its command to suppress the insurrection. ${ }^{16}$ In this instance foreigners (Finns) were also fighting on the side of the rebels. ${ }^{17}$

Also outside the capitals, Latvians and internationalists were used to suppress revolts. In January 1918 the Latvians suppressed the mutiny of a Polish corps under command of General Dowbór-Muśnicki in White Russia, and in February 1918 they fought against the anti-Bolshevik forces of General Kaledin in the Don region. Latvians and internationalists took part in suppressing insurrections in Iaroslavl', Rybinsk (today Andropov), Izhevsk-Votkinsk (Izhevsk now Ustinov), and many other places. They also fought against the insurgent Czech Legion in the Volga region. ${ }^{18}$ When in 1918 the peasants' refusal to sell their produce at the state-fixed price led to a food crisis, the Government organized crop-requisition campaigns in which, again, in addition to others, Latvians and internationalists were enlisted. ${ }^{19}$

Estimates of the number of Latvian Rifles fighting for the Bolsheviks in Russia in 1918 vary between fourteen thousand ${ }^{20}$ and twenty-four thousand. ${ }^{21}$ Most of these soldiers came to Russia after the German occupation of Livonia in February 1918, other parts of Latvia having been occupied earlier. The principal reason for the vital importance of the Latvians and the internationalists to the Bolshevik cause during the first few months after the October Revolution was the fact that at the time the Red Army still was in its infancy. It was founded in the spring of 1918, and the Latvian Rifle Division formed in April under command of Colonel I. I. Vatsietis was the first division of the new army. In September the Latvian Colonel was appointed Commander-in-Chief of the Red Army, a position he held until July 1919.

By the end of 1918, after the German defeat, the main part of the Latvian Rifles returned to Latvia. They constituted the majority of the Soviet army under command of Vatsietis that, in January 1919, expelled the "bourgeois" government of an independent Latvia under K. Ulmanis from the capital Riga. The Latvian Soviet Republic, however, could not hold out for more than a few months, and soon the Red Army had to abandon the

16 I. I. Vatsietis, quoted in G. Leggett, The Cheka: Lenin's Political Police (Oxford, 1981), p. 76; A. Kolman, Die verirrte Generation (Frankfort/M., 1979), p. 95.

${ }_{17}$ Scheibert, Lenin an der Macht, pp. 72, 427.

18 Vatsietis, quoted in Bunyan, Intervention, Civil War, and Communism in Russia, op. cit., p. 292.

19 See, e.g., Kolman, Die verirrte Generation, op. cit., p. 96.

${ }^{20}$ Maksudov, "Internatsionalisty i russkaia revoliutsiia", in: Vestnik Russkogo Khristianskogo Dvizheniia, No 131 (1980), pp. $233 \mathrm{f}$.

21 Istoriia latyshskikh strelkov (Riga, 1972), p. 230; A. Ezergailis, The Latvian Impact on the Bolshevik Revolution (Boulder, 1983), p. 365. 
struggle against independent Latvia. Part of the Latvian Rifles again moved to Russia, where together with other internationalists they took part in the fighting against the White Generals Denikin and Vrangel' in Southern Russia. Latvians, Estonians and Chinese were also brought into action against Makhno and his Anarchists, and the deployment of such foreign forces is also mentioned at the suppression of the Tambov ${ }^{22}$ and Kronstadt uprisings..$^{23}$

Among the internationalists mention may be made of such figures as Béla Kun. He left Russia to lead the Hungarian Soviet Republic in 1919, returning, however, after the fall of his Government to participate in the liquidation of Vrangel"s followers on the Crimean Peninsula. ${ }^{24}$ The Croatian Josip Broz (Tito) served with an internationalist unit at Omsk in Siberia. ${ }^{25}$ The Czech Jaroslav Hašek, author of The Good Soldier Švejk, disseminated Bolshevik propaganda among the former prisoners of war in Siberia. ${ }^{26}$ Many Latvians occupied leading positions in the Red Army (Vatsietis, Eikhe, Smilga, etc.), the Cheka (Latsis, Peters, etc.), and the State administration or the party (Stuchka, Pel'she, etc.). Among the prison warders were many Latvians, ${ }^{27}$ as well as Hungarians and other foreigners. ${ }^{28}$ This may have been a tactical move, as these warders could hardly speak Russian, if at all. Hence they did not easily communicate with the prisoners. In later years, under the Stalin rule, the Latvians and the internationalists who had remained in Russia came to a bad end. They were liquidated and their names were removed from the history books.

Historical treatment of the internationalists and of the Latvian Rifles has frequently been coloured by ideologically subjective arguments. During the first years after the Revolution, and again during the post-Stalin years (though with less emphasis), Soviet historians have portrayed the activities of the internationalists as being some form of "brotherly aid of the international proletariat extended to the Socialist Revolution", thereby

22 O. H. Radkey, The Unknown Civil War in Soviet Russia (Stanford, 1976), pp. 205f.; Scheibert, Lenin an der Macht, p. 73.

${ }_{23}$ P. Avrich, Kronstadt 1921 (Princeton, 1970), pp. 193f.; A. Balabanoff, Impressions of Lenin (Ann Arbor, 1964), pp. 58f.; F. I. Dan, Dva goda skitanii (Berlin, 1922), p. 154; Scheibert, Lenin an der Macht, p. 370.

${ }_{24}$ R. L. Tökes, Béla Kun and the Hungarian Soviet Republic (New York, 1967).

25 Ph. Auty, Tito. A Biography (London, 1970), pp. 35-38.

26 Kolman, Die verirrte Generation, p. 108; G. Thunig-Nittner, Die tschechoslowakische Legion in Russland (Wiesbaden 1970), p. 228.

${ }^{27}$ Che-Ka. Materialy po deiatel'nosti chrezvychainykh komissii (Berlin, 1922), p. 154; Leggett, The Cheka, op. cit., p. 263; A. Solzhenitsyn, Arkhipelag Gulag, I-II (Paris, 1973), p. 197; Ezergailis, The Latvian Impact, op. cit., p. 15.

28 Che-Ka, pp. 179, $192 \mathrm{f}$. 
underlining the international character of the Revolution. This could lead to an exaggerated emphasis on the role played by the internationalists. By contrast, the strong Russian chauvinism under Stalin resulted in a de-emphasis of their role.

Russian anti-Communists have at times likewise accentuated the role played by the internationalists in the Revolution in arguing that it was largely imposed from without. Such views were not only propagated during the first few years after the Revolution. Over the past ten years or more anti-Communist Russian nationalists have also stressed the role of the internationalists. In his contribution to the collection Iz-pod glyb (From Under the Rubble) of 1974 Solzhenitsyn for the first time stresses the significance of what he calls "the international forces of the revolution".

Did not the revolution throughout its early years have some of the characteristics of a foreign invasion? When in a foraging party, or the punitive detachment which came down to destroy a rural district, there would be Finns and there would be Austrians, but hardly anyone who spoke Russian? When the organs of the Cheka teemed with Latvians, Poles, Jews, Hungarians, Chinese? When in the critical early phases of the civil war it was foreign and especially Latvian bayonets that turned the scales and kept the Bolsheviks in power? ? $^{29}$

In the same article Solzhenitsyn mentions the Latvians and the Hungarians "whose rifles barked often enough in the cellars of the Cheka and the backyards of Russian villages". ${ }^{30}$ Elsewhere in this collection he reiterates: "We have already experienced that fight (carried out with Latvian bayonets and Magyar pistols) with our ribs and the backs of our necks, no thank you!" 31

This view of the Soviet regime as occupying power has been further elaborated by another recent emigrant from the Soviet Union, Mikhail Bernshtam, a supporter of Solzhenitsyn. ${ }^{32}$ According to Bernshtam, in an article of 1979 , the Bolsheviks after coming to power did not enjoy sufficient support amongst the population and were forced to rely on outsiders to maintain their position. These forces consisted of the denationalized internationalists, a kind of "mercenaries [landsknekhty] of the Revolution", ${ }^{33}$ deployed to control the rebellious national population. Until the

29 Iz-pod glyb. Sbornik statei (Paris, 1974), p. 135; English translation: From Under the Rubble (Boston, 1974), p. 125.

${ }^{30}$ Iz-pod glyb, p. 141; From Under the Rubble, p. 132.

${ }^{31}$ Iz-pod glyb, p. 247; From Under the Rubble, p. 264.

32 M. Bernshtam, "Storony v grazhdanskoi voine 1917-1922 gg.", in: Vestnik Russkogo Khristianskogo Dvizheniia, No 128 (1979), pp. 252-357.

33 Ibid., p. 331. 
fall of 1918, i.e., when the mobilized units of the Red Army were still small in numbers, the internationalists and in particular the Latvian Rifles ${ }^{34}$ were "the principal military force in the principal operations, viz., in suppressing popular risings". ${ }^{35}$ Thus, during the Civil War and particularly during the critical first year after the Revolution the internationalists played "a key role in the victory of the regime over the people". ${ }^{36}$ Hence the Socialist ${ }^{37}$ regime in Russia was essentially an "occupational regime", and the Civil War was "an internationalist-socialist occupation of Russia". ${ }^{38} \mathrm{By}$ the fall of 1918 the Soviet regime according to Bernshtam commanded 74,000 internationalist troops including the former prisoners of war and 24,000 regulars of the Latvian Rifle Division. ${ }^{39}$ This amounts to 19 per cent of the Red Army, at that time numbering some 400,000 troops. Towards the summer of 1920 the number of internationalists had increased to 268,000 troops, 18,000 of them in the Latvian Rifle Division, all in all amounting to 7.6 per cent of the Red Army, by then expanded to a force of about 3.5 million..$^{40}$

Bernshtam's article provoked a reaction by an author writing under the name of Maksudov, likewise a recent emigrant from the Soviet Union. ${ }^{41}$ Maksudov begins expressing disbelief in an argument claiming that 75,000 foreigners could manage to subjugate a nation of many millions which, by the way, offered fierce resistance. Besides, he believes the number of 75,000 is rather exaggerated. In 1918 the Soviet Government, in fact, commanded some 11,000 internationalists in addition to 14,000 Latvian Rifles, together about 25,000 troops. Instead of 19 per cent this makes for about 7 per cent of the Red Army. ${ }^{42}$ These forces were by no means as reliable as Bernshtam and others want us to believe. Moreover, inside Russia the Bolsheviks had to deal with the resistance of an even greater number of foreign soldiers. Among the forces fighting against the Red Army during the Civil War were altogether some fifty to one hundred thousand former prisoners of war, of whom 35,000 to 50,000 belonged to the famous Czech Legion. ${ }^{43}$ Finally, the Latvian Rifles could not in fact be

${ }^{34}$ Bernshtam reckons the Latvian Rifles among the internationalists.

${ }^{35}$ Bernshtam, "Storony v grazhdanskoi voine", loc. cit., p. 332.

36 Ibid., p. 333.

37 Bernshtam takes "Socialist" and "Communist" to be synonymous.

38 Ibid.

${ }^{39}$ Bernshtam claims to have left out several other categories of internationalists.

to Ibid., p. 332.

${ }^{41}$ Maksudov, "Internatsionalisty i russkaia revoliutsiia”, loc. cit., pp. 221-62.

42 Ibid., pp. $233 \mathrm{f}$.

${ }^{43}$ Ibid., pp. $230 \mathrm{f}$. 
dubbed foreigners, as they had been mobilized by the Tsarist Government being citizens of the Russian Empire.

Maksudov claims that after the autumn of 1919 internationalists had ceased to play a role in the Russian Civil War. He sees Bernshtam's figures for 1920, viz., 250,000 internationalists and 18,000 Latvians, as grossly exaggerated. By the summer of 1920 the internationalist units comprised some 13,000 to 16,000 troops, in addition to some 8,000 Latvians. Together this amounts to no more than 24,000 troops or about 0.8 per cent of the Red Army, not 7.6 per cent. ${ }^{44}$ Maksudov agrees that the Bolsheviks were not supported by the majority of the people. He believes, however, that it was primarily Russians who put them in the saddle and who kept them there. Of the regulars in the Red Army a vast majority were Russian workers and peasants. ${ }^{45}$ This view is confirmed by the first general census in Soviet Russia in August 1920, from which it appears that Russians constituted almost 80 per cent of the Red Army in contrast to just over 50 per cent of the total population..$^{46}$

Evaluation of the role played by the internationalists and the Latvian Rifles in the Civil War is hampered by a lack of reliable statistical data. The general census mentioned by Maksudov does provide this kind of information. Usually, however, quoted figures appear without convincing backing. One detects the tendency of these figures to become inflated with repeated use. ${ }^{47}$ Not all historians have been misled thereby. According to the American historian of the Red Army, John Erickson, the internationalist units were never large and they "never played any significant military role". ${ }^{48}$ George Kennan, the historian of Soviet-American relations during

44 lbid., p. 238.

45 Ibid., pp. 229, 242-46.

46 Id. " 'La composition nationale de l'Armée rouge d'après le recensement de 1920", in: Cahiers du Monde Russe et Soviétique, XXIV (1983), pp. 483-92. Bernshtam's reply to Maksudov's article of 1980: "Mikrob kommunizma ili tifoznaia vosh'?", in: Vestnik Russkogo Khristianskogo Dvizheniia, No 131, pp. 263-324; Maksudov's reaction: "O nekorrektnom ispol'zovanii istochnikov", ibid., No 135 (1981), pp. $292 \mathrm{f}$.

47 For instance, 30,000 to 40,000 Chinese: Erickson, The Soviet High Command, op. cit., p. 675; Bernshtam, "Mikrob kommunizma ili tifoznaia vosh'?", p. 306; or even 40,000 to 50.000 Chinese: Iu. Srechinskii in Novoe Russkoe Slovo, May 29, 1966; 10,000 Koreans: Grazhdanskaia Voina i Voennaia Interventsiia, op. cit., p. 288 (Srechinskii: 10,000 to 12,000 Koreans); 100,000 Hungarians: Tökes, Béla Kun and the Hungarian Soviet Republic, op. cit., p. 70; 100,000 Poles, 30,000 Yugoslavians, 10,000 pro-Bolshevik Czechs: The Modern Encyclopedia of Russian and Soviet History, XIV, p. 212; Sovetskaia Istoricheskaia Entsiklopediia, VI, p. 160 (Srechinskii: 12,000 Czechs).

48 J. Erickson, "The Origins of the Red Army", in: Revolutionary Russia, ed. by R. Pipes (Cambridge, Mass., 1968), pp. 224-56, quote on p. 253; on p. 229, however, Erickson considers the internationalist units "small in number but potent in influence". 
this period, also writes that the number of prisoners of war induced to sign up with the Communists remained "remarkably small". He approvingly cites a contemporary estimate that placed the number of those armed in all of Russia at 15,000. According to Kennan, the considerably higher figures given in Communist sources may have included many who signed up and were not actually armed. ${ }^{49}$ Also it has been claimed that Hungarian ex-POWs while returning enrolled in internationalist units, often doing so in each Siberian garrison town they passed; this resulted in their being counted several times..$^{50}$

More can be said about the reasons why Latvians, Hungarians, Chinese, etc., became engaged in a civil war taking place at a great distance from their home country. Communists ${ }^{51}$ as well as some anti-Communists want us to believe that it was a matter of international proletarian solidarity. The latter may even speak of "elements entirely estranged from their home country" 52 or "traitors of their homeland". ${ }^{53}$ One may well question this argument, as the majority of the internationalists eventually returned home. It seems that to the Hungarians and other former prisoners of war it always was the principal objective. But in order to achieve it the war with Germany and its allies had to end, and for this the Bolsheviks offered more hope. In addition to the attraction exerted by some of the Bolshevik slogans there were other benefits, such as food and clothing, so welcome after the rough time most prisoners of war had in the camps. The opportunity of promotion and the prospect of fame may also have played a role. ${ }^{54}$ To most of the Czechs the issue was different. Their overriding ambition was to achieve Czech independence, and to this end to join the Allied forces against the Austro-Hungarian army. When the Bolsheviks tried to block their passage, they rose in revolt. The existing enmity between Czechs and Hungarians also contributed to this conflict, and indeed served as the initial spark. ${ }^{55}$

An explanation of the participation of the Latvian Rifles in the Russian Civil War should also, at least partly, be found in motives related to nationality. During the period prior to the Revolution the Social Democrats had become the principal opposition in Latvia. This movement

${ }^{49}$ G. F. Kennan, The Decision to Intervene (London, 1958), pp. 73f.

50 Péter Sipos (Budapest) in a discussion during the symposium on Internationalism in the Labour Movement before 1940, Amsterdam, September 1985.

51 See, e.g., Istoriia latyshskikh strelkov, op. cit., pp. 13, 722.

52 See note 8.

53 Nefedov in Veche, No 4, p. 109; No 6 (1982), p. 89.

${ }_{54}$ Cf. Tökes, Béla Kun and the Hungarian Soviet Republic, p. 70.

55 Thunig-Nittner, Die tschechoslowakische Legion, op. cit., p. 51. 
had a strong nationalist content and it was directed against both the Tsarist Government and the Baltic-German squires, who still were the major landowners. In the course of 1917 the Bolsheviks managed to take over leading positions in Latvian Social Democracy, and under their leadership the Social Democrats won a number of elections in the period 1917-18. Thus the Latvian Rifles fought for the most popular political movement in Latvia. During the better part of the year 1918 they could not go back home, as many Russian soldiers of the old army did, for Latvia still was entirely occupied by the Germans. After the establishment of a Latvian Soviet Republic the popularity of the Bolsheviks quickly waned, and many Latvian Rifles now chose for an independent "bourgeois" Latvia. Others, however, returned to Russia and fought on the Bolshevik side until the end of the Civil War, after which most of these soldiers returned to Latvia. ${ }^{56}$

It is beyond any doubt that it was not Russians alone who made the victory of the Bolsheviks possible. The internationalists and the Latvian Rifles have, particularly at the outset, played an important role and their contribution to the events of 1917 and after deserve further study. Available evidence does not, however, support claims of a "foreign invasion" (Solzhenitsyn) or an "internationalist occupation" (Bernshtam).

56 For background information see U. Geerrmanis, Oberst Vācietis und die lettischen Schützen im Weltkrieg und in der Oktoberrevolution (Stockholm, 1974); Ezergailis, The Latvian Impact. 